\title{
Age-related Microscopic Changes in the Thyroid Gland of West African Dwarf Goat During Foetal and Post-natal Periods of Development
}

\author{
Casmir O. IGBOKWE*, Daniel N. EZEASOR \\ University of Nigeria, Faculty of Veterinary Medicine, Department of Veterinary Anatomy, Nsukka, \\ Nigeria; casmir.igbokwe@unn.edu.ng (*corresponding author);dezeasor@yahoo.com
}

\begin{abstract}
The histometric and histologic standard techniques were used to provide comprehensive information on the morphological changes in the thyroid gland of West African Dwarf goat during the foetal and postnatal development stages. The foetal age was determined using crown rump length and the pre-pubertal and pubertal age of animals was determined by dentition. The early foetal thyroid, surrounded by a thin capsule of dense irregular connective tissue, was continuous with well vascularised loose connective tissue septa. The parenchyma was composed of solid cell clusters of follicular epithelial cells surrounding small lumina. Follicular arrangement was indistinct in foetal thyroid by 50-70 days of gestational age and many follicles of different sizes were present by 95-125 days onwards. Significant variations in the mean follicular diameter, mean capsule thickness and mean epithelial cell height of the thyroids were observed in all stages of development. The mean large follicular diameter in the foetal, pre-pubertal and pubertal ages were $17.70 \pm 0.09 \mu \mathrm{m}, 54.41 \pm 0.28 \mu \mathrm{m}, 142.77 \pm 0.51 \mu \mathrm{m}$ respectively. The follicular cells were of low cuboidal shape in foetuses, assumed high cuboidal or columnar form in prepubertal group and squamous in older pubertal age. Ultimobranchial follicles were encountered in early foetal goat thyroids, while focal areas of follicular cell hyperplasia were frequently seen in the older pubertal thyroids. The strong PAS-positive reaction increased strikingly from the 95-125 days foetal age, and by pubertal age all follicles were fully distended with colloid. Colloid vacuolation (colloid droplets) were encountered frequently by the age of 95-125 days, indicating the ability to synthesize hormones towards the last trimester of gestation. Parafollicular cells were distinguished by its pale cytoplasm and large nucleus at 75-90 days onwards. They were located basally and as clusters in the interfollicular tissue. This finding suggested possible high prenatal function for the thyroids of goats in the synthesis of thyroid hormones.
\end{abstract}

Keywords: development, goat, histology, histometry, thyroid

\section{Introduction}

The thyroid gland is a profusely vascular, bilobed, endocrine organ situated at the base of the larynx. It largely extends to the tracheal rings in many animal species (Venzke, 1975). Histologically, it consists of two types of cells: follicular cells and parafollicular cells (Fujita, 1975). The follicular cells synthesize and secrete thyroid hormones, which are acknowledged as a virtually universal requirement for maintenance of normal levels of metabolic activity. The hormones influence many aspects of reproduction, growth, differentiation and metabolism (Norris, 2007). The thyroid hormones co-operate with many other hormones to enhance the effectiveness of these functions. The parafollicular (C) cells of thyroid secrete calcitonin, a calcium-reducing hormone with antagonistic effects to parathyroid hormone (Norris, 2007). Deficient or excessive production of thyroid hormones may lead to serious pathological states with outward symptoms. Secretion of these hormones is regulated by thyroid stimulating hormones released from the anterior lobe of pituitary gland (Young and Heath, 2000).

The West African Dwarf (WAD) goat provides meat, milk and skin for many rural and urban dwellers in West Africa. It also meets the cultural and recreational needs in developing countries of West Africa (Solaiman, 2010). Intensive research studies are being carried out in order to understand the biology of the goat, which could lead to its genetic improvement and productivity.

Well known variations in the histology of the thyroid gland do exist between domestic animals (Fujita, 1975). The gland generally shows similar follicular structure amongst vertebrates. In addition, thyroid parafollicular cells undergo significant morphological alterations during the prenatal and post-natal period of development (Schafie and Mashally, 1974). These alterations relate to the number of cells, histological and 
60

ultrastructural changes and the hormone storage ability of the cells (Kameda et al., 1984). The thyroid responses to environmental and nutritional influences also differ among domestic animals. Few published articles on caprine thyroid morphology (Roy et al., 1976, 1978a, 1978b; Baishya et al., 1985, 1986; Adhikary et al., 2003; Bhardwaj et al., 2006; Hamad, 2008) have mostly been focused to the exotic breeds of goats. Moreover, the foetal and post-natal histological alterations of the thyroid during growth were not considered in these studies.

The present study aimed to provide comprehensive information on the microscopic changes of the thyroid gland of WAD goat during the foetal and post-natal periods of development. The information obtained will serve as baseline data that may be useful in clinical and pathological diagnosis of thyroid problems in goat.

\section{Materials and Methods}

\section{Experimental animals}

A total of 60 paired foetal thyroid lobes were obtained from foetuses of pregnant goats unknowingly slaughtered for meat in the local abattoirs in Nsukka and Obollo-Afor, Enugu State, Nigeria, just before singeing of the carcass. The age of foetuses were determined by prediction formula (Richardson, 1980) and by visual observation of developmental features [Prediction formula: $\mathrm{Y}=(\mathrm{CRL}+$ 17) 2.7 , where $Y$ is the age (days) and CRL $=$ Crown to Rump Length $(\mathrm{cm})]$. The thyroid glands were obtained from ten each of prepubertal and pubertal goats comprising postnatal goats purchased from markets around the University of Nigeria, Nsukka and maintained for about two weeks in order to ascertain that they were in good health condition for the study. The age of the prepubertal and pubertal goats were determined by dentition (Chibuzo, 2006; Solaiman, 2010).

\section{Histological procedure}

For histological study, thin slices taken from different parts of each thyroid lobe in the central and peripheral areas, and isthmus were fixed in $10 \%$ neutral buffered formalin and processed routinely. The sections were cut at $5 \mu \mathrm{m}$ thickness and stained with Hematoxylin and Eosin and Periodic Acid Schiff (PAS) and mounted in Entellan. Several selected stained sections were used to obtain some morphometric parameters of the thyroid gland components at various stages of development with the help of an ocular micrometer gauge calibrated with a stage micrometer under a light microscope at $\times 400$ magnification. These parameters were: thickness of capsule, follicular peculiarities (small, medium and large; regular or round) and height of follicular epithelial cells. Photomicrographs were obtained with digital camera attached to the microscope.

\section{Data analysis}

Using SPSS Version 16.0 for Microsoft Windows, the mean and standard error of mean (SEM) of each parameter were computed for each development age. Data were analysed statistically using analysis of variance. Duncan's multiple range test was used to separate variant means, and significance was accepted at $\mathrm{p}<0.05$.

\section{Results}

\section{Histological features}

Foetuses of 50-70 days

The thyroid gland consisted of connective tissue capsule composed of collagenous fibers. Fibroblast and blood vessels were also present in the capsule. Rudiments of parathyroid gland made contact with the thyroid gland. The trabeculae extended from the capsule into the parenchyma of the gland, dividing it into lobules. Blood vessels, including capillary network, lymphatics and fibrocytes were observed in the connective tissue of these septal trabeculae. Highly vascularised strands of connective tissue separated the follicles and large number of capillaries formed extensive network between follicles (Figs. 1A, B). In some areas, cords of four to six cells were present without obvious organisation into follicles and there was no colloid. Moderate variations in the size of the predominant small follicle were often seen in different sections of same thyroid lobe. Groups of small follicles were predominantly present by about 50 days of age. Each follicle was surrounded by copious vascular elements (perifollicular vascular sinuses). About four to seven cords of follicular cells were present in each follicle. In some follicles, there were no lumina in the centre of clumps of mitotic cells. Some of the small follicles in the centre of the gland contained lumen with faintly eosinophilic, PAS positive colloid (Figs. 1C, D), whereas others were empty. The follicular epithelium were generally low cuboidal in most follicles and variations in epithelial cell height were not noticed between follicles. The parafollicular cells were not distinguishable from follicular cells at this age.

However, by 70 days of gestation, the capsule of thyroid had matured further in content and organisation of collagenous tissue, increased in fibroblasts and vascular structures which completely housed the parenchyma. Trabeculae also divided the parenchyma into indistinct lobules with numerous follicles and vascular elements amongst other connective tissue elements were interposed between follicles like in the foetuses of 50 days. Blood elements were also present beneath the capsule. The follicles were predominantly small in size, but few medium-sized follicles were apparent, as well as unusually shaped, elongated follicles. These unusual follicles with stratified follicular epithelium were presumed to be ultimobranchial follicles (Fig. 1D). Occasionally, they were present in the central zone of the gland and contained low cuboidal to columnar follicular cells greater in number than other follicles. The few medium-sized follicles appeared to be concentrated on the peripheral zone of the gland, in groups of about 15 to 20 follicles. All types of follicles contained deeply stained eosinophilic colloid in their lumen, surrounded by about 7-12 low cuboidal follicular cells with intervening interfollicular connective tissue (Fig. 2A). The unusual follicle also contained colloid surrounded by greater number of cells with the epithelium appearing more columnar. Few large follicles contained faintly stained low cuboidal follicular cells. By 70 days, there was a great reduction in the profiles of vascular sinuses seen in interfollicular connective tissue.

\section{Foetuses of 75-90 days}

The components of the thyroid capsule and trabeculae were retained as they showed further maturation. The capsule was richer in blood vessels, collagen fibers, fibroblasts and nerve bundles. From the capsule, trabeculae penetrated the gland 

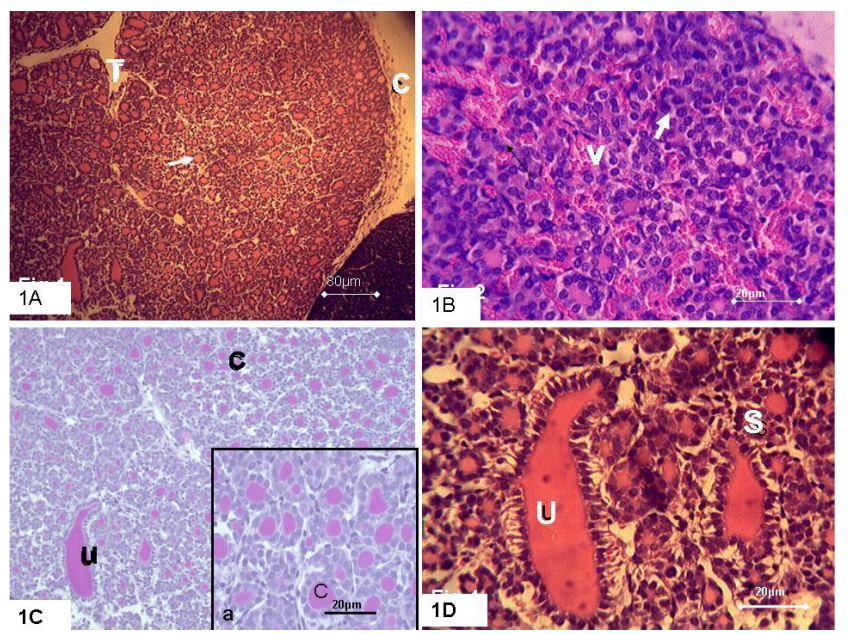

Fig. 1A. Photomicrograph of section of foetal thyroid (50-70 days), showing developing capsule (C), parathyroid (P), trabeculae $(\mathrm{T})$ and parenchyma with numerous small sized follicles (arrows), some cells were in cords without definite organization. H - E (bar scale: $80 \mu \mathrm{m}$ ); Fig. 1B. Thyroid sections showing highly vascular parenchyma $(\mathrm{V})$ and mitotic cells and cell cords without lumen (arrow heads). H - E (bar scale: $20 \mu \mathrm{m}$ ); Fig. 1C. Photomicrograph of foetal thyroid of WADG (50-70 days): showing PAS positive colloid with some unusual irregular follicle (arrow) present. Small follicles were predominant. Some do not contain colloid. PAS (scale bar 80 $\mu \mathrm{m})$; Fig 1D. Photomicrographs of sections of thyroid (50-70 days) showing unusual elongated follicles presumed to be ultimobranchial follicles (U) surrounded by small-sized follicles (S). H - E (bar scale $20 \mu \mathrm{m}$ ).

parenchyma forming lobules as seen previously. The number of follicles increased with interfollicular connective tissue containing blood vessels and fibroblastic cells (Fig. 2B). The medium follicles predominated followed by large follicles and then the few small follicles located peripherally. The medium and large-sized follicles were closer to the centre of gland, while the small follicles were abundant in the peripheral zone. The small follicles possessed about 12-15 low cuboidal follicular cells and high cuboidal epithelium in some follicles in the centre of the gland. In addition, the medium follicles had about 15-20 cells, while that in the large follicles were about 25-30 cells. Majority of the follicles showed a colloid-filled lumen irrespective of the follicular size and were strongly PAS positive (Fig. 2C). However, follicles without colloid were also present. The thyroid isthmus also possessed follicles with increased number of cells by this age of development and with colloidfilled lumen. Few medium follicles had empty lumen without colloid. The colloid stained homogenously in all follicles. Parafollicular cells were present and distinguished by its pale cytoplasm and large nucleus (Fig. 2D). These cells appeared in between follicular cells basally and sometimes as clumps in the interfollicular connective tissue.

\section{Foetuses of $95-125$ days}

Connective tissue of the capsule showed further maturation with clear invagination into the stroma dividing into pseudo-lobules, with adipose tissue present amongst collagen fibrils, fibroblasts, blood vessels and nerve bundles

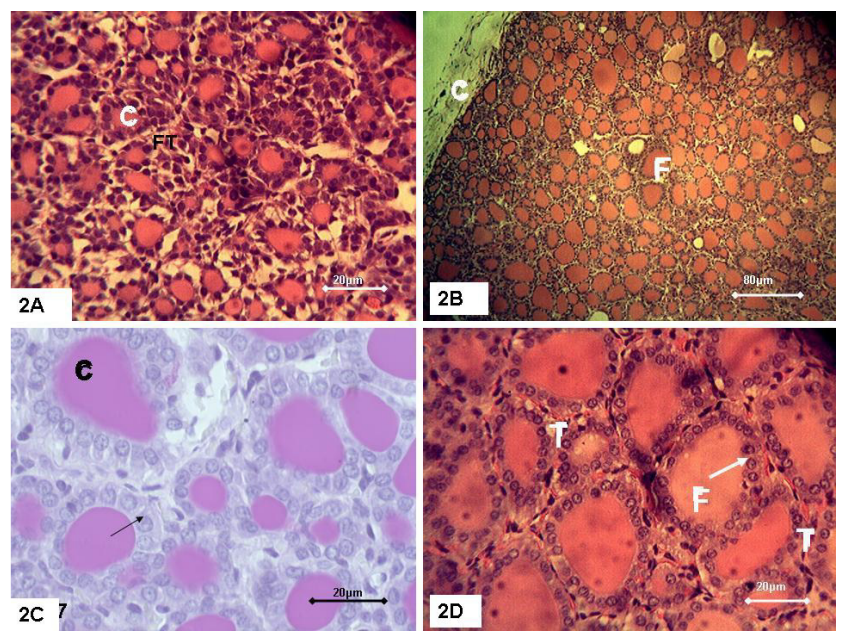

Fig. 2A. Photomicrograph of sections of 50-70 days WADG, showing the presence of small follicles (arrows) with few cells (4-7), filled with eosinophilic colloid, H \& E (scale bar $20 \mu \mathrm{m}$ ); Fig. 2B. Photomicrograph of thyroid sections of foetal WADG (75-90 days), showing maturing capsule (C), small follicles in the periphery and medium-sized follicles with large-sized follicles $(\mathrm{F})$ predominant in the inner zone of the glands; some follicles without colloid. H - E (bar scale $80 \mu \mathrm{m}$ ); Fig. 2C. Sections 75-90 days thyroid showing increased number of follicular cells (arrow) and deeply stained PAS-positive colloid (C). PAS (scale bar $20 \mu \mathrm{m}$ ); Fig. 2D. Thyroid sections of 75-90 days showing increased number of follicular cells from the previous age, Follicular lumen (F) and Parafollicular cells (arrow) apparent. Note a well vascularised interfollicular tissue (T). H - E (bar scale $20 \mu \mathrm{m})$

(Fig. 3A). The fibrous connective tissue stroma of trabeculae containing vascular structures and nerves entered from the capsule into the parenchyma, dividing it into indistinct lobules (pseudo-lobules) that contained numerous follicles of varied size. Numerous irregularly shaped, large and medium follicles distended with colloid predominated over small follicles (Fig. 3B). The small follicles appeared to be localized more in the central zone, while the other sizes were mixed-up in arrangement close to the periphery of the gland. The follicles had 45-50 follicular cells in large ones, 15-20 in medium-sized ones and 8-12 cells in the small follicles. Several unusually elongated large follicles distended with colloid were present. The follicular epithelial height varied from one follicle to the other, from low cuboidal to high columnar, depending on the presence of colloid droplets (Fig. 3C). These were usually present at the periphery of the colloid as white rim in sections and indicated follicular activity. In some highly colloid-distended follicles without colloid droplets, the cells were low cuboidal or squamous, while cells with moderate colloid and colloid droplets were columnar. Stratified follicular epithelial cells representing ultimobrachial follicles often invaginated into the follicular lumen. Colloid droplets in the periphery of PAS-positive colloid were encountered in some of the medium-sized and small follicles (Fig. 3D). Interfollicular connective tissue contained moderate vascular structures. Centrally, the gland showed extensive capillary network with several follicles and peripheral colloid droplets. Few parafollicular cells with large 
62

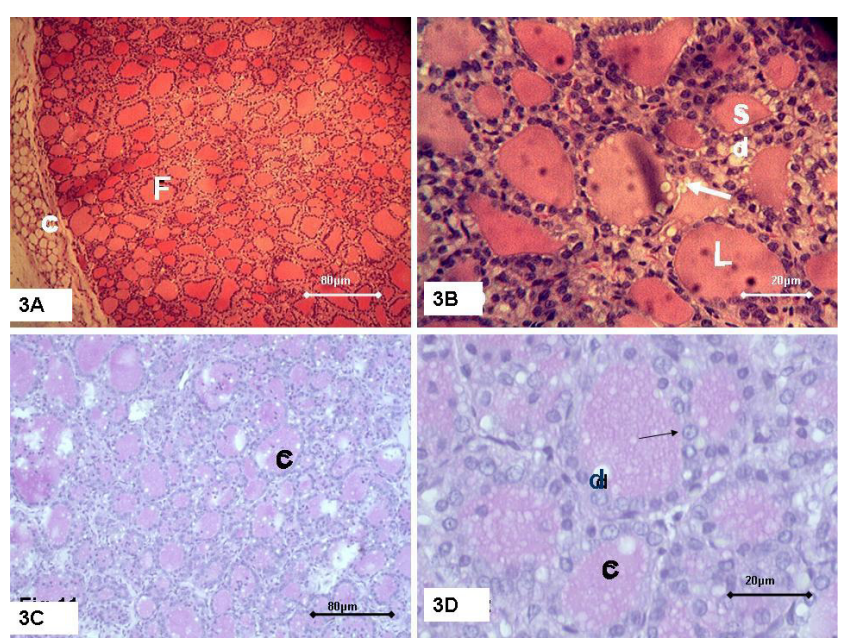

Fig. 3A. Photomicrograph of thyroid section of foetal WADG (95-125 days), showing thyroid gland with well-developed thyroid parenchyma containing several large follicles with colloid droplets (vacuoles) concentrated close to the centre of the gland; the capsule of the gland (C) well developed with some adipose tissue. $\mathrm{H}-\mathrm{E}$ (bar scale $80 \mu \mathrm{m}$ ); Fig. 3B. Sections of 95-125 days thyroid taken close to the centre of the gland with follicles containing numerous colloid droplets (arrow) and completely filled with colloid, follicular cells invaginated into the lumen (L). Small follicles $(\mathrm{S})$ also seen. H - E (scale bar $20 \mu \mathrm{m}$ ); Fig. 3C. Photomicrograph of section of 95-125 days thyroid with several elongated follicles that contained colloid (C). H - E (bar scale $80 \mu \mathrm{m}$ ); Fig. 3D. Sections of 95125 days thyroid with strongly stained PAS-positive colloid (C) with peripheral colloid droplets (d), Parafollicular cell (arrow) is apparent. PAS (bar scale $20 \mu \mathrm{m}$ ).

nucleus and pale cytoplasm were present basally amongst follicular cells similar to early stages of development.

\section{Pre-pubertal WADG (The West African Dwarf Goat)} of $2-4$ months

The capsule and the radiating trabeculae of the thyroid gland by this age did not show any feature different from the previous observations. Several follicles of different sizes were present, with the large follicles more in number, located centrally and oval to spherical in shape. Small follicles were regular in shape, but highly irregular ones were also seen occasionally. The number of follicular cells were about 28-35 in number in large follicle, 20-25 cells in medium follicle and 10-12 cells in small follicles. Colloid droplets were present in the periphery of the colloid of follicles situated mainly at the periphery of the organ next to the capsule (Figs. 4A, B). The size of follicular lumen was larger in the central regions than in the peripheral regions. All follicles apparently had strongly PAS positive colloid in their lumen (Fig. 4C, D). The follicular epithelial height did not significantly differ from the previous observations and were high cuboidal to columnar in most follicles. Rarely, large follicles with low cuboidal or even squamous shape were encountered. Generally irregular follicles increased in number with increasing age and were more common in the pubertal animal.

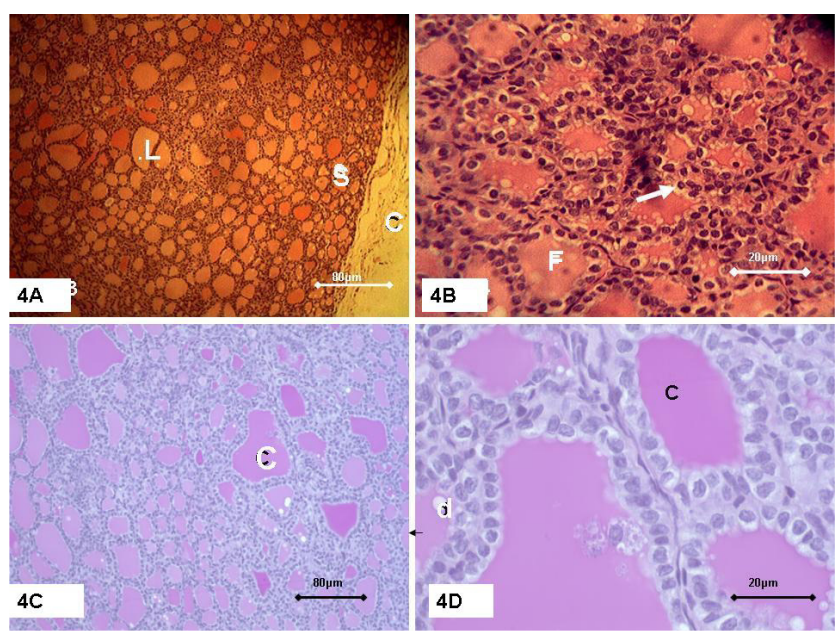

Fig. 4A. Photomicrograph of thyroid prepubertal WADG (2-4 months) goats with several follicles of different sizes with the large follicles $(\mathrm{L})$ appearing more in number and located in the centre of the gland, small follicles $(S)$ are at the periphery with capsule (C). H - E (bar scale $80 \mu \mathrm{m})$; Fig. 4B. Photomicrographs of 2-4 months thyroid showing the follicular cells surrounding follicles (F) are cuboidal and columnar in places and Colloid droplets (arrow) are present on the rim of the colloid. H - E (bar scale $20 \mu \mathrm{m}$ ); Fig. 4C. Photomicrograph showing thyroid of 2-4 months goat showing PAS- positive colloid 0n all follicles. PAS (bar scale 40 $\mu \mathrm{m})$; Fig. 4D. Sections of 2-4 months goat thyroid at higher magnification showing colloid droplets (d) and follicles (F) surrounded by follicular cells. PAS (bar scale $20 \mu \mathrm{m}$ ).

\section{Pubertal WADG (1-2 years)}

The thyroid gland showed fully matured capsular connective tissue with pseudo-lobular arrangement of the parenchyma and interfollicular connective tissue. Large, medium and small-sized follicles well distended with colloid were present. Colloid droplets were prominent in the small and medium follicles (Fig. 5A). The large follicles had cuboidal epithelium with squamous cells lining the follicles well distended with colloid. The small follicles had 10-15 cells; the medium follicles had 20-30 and large follicles with 40 cells. Stratified columnar follicular cells invaginated into the lumen in some small follicles and most of these resembled the ultimobranchial follicles in the foetal stage, but generally the epithelium was high cuboidal with consistent colloid droplets in most small and medium follicles. The large follicles had low cuboidal epithelium with cell nuclei lying on the base of the cell. Very few large follicles at the periphery of the organ possessed squamous cells with scant colloid droplets around the periphery of the strongly PAS positive colloid (Fig. 5B). Interfollicular connective tissue was well defined with vascular tissue and few connective tissue cells. Occasionally, fibrotic areas appeared to be present in the interfollicular connective tissue. Parafollicular cells with large nucleus and thin, lightly stained cytoplasm were encountered between follicular cells clearly in the PASstained sections. 


\section{Pubertal WADG (over 3 years)}

The histological features of thyroid gland differed from the previous ages by the presence of predominantly large follicles, hyper-distended with colloid. Colloid droplets were sparse in the rim of the follicular colloid in these large follicles. There were few small follicles present. Medium-sized follicles intermingled with large follicles (Fig. 5C). The small follicles and very few medium follicles retained a high cuboidal epithelium, the large-sized follicles presented low cuboidal cells and even squamous cells. Unusual follicles, resembling ultimobranchial follicles, were present with little colloid in their lumen mixed up with cellular debris. The fibrotic areas of the interfollicular connective tissue encountered in the previous age group increased. Numerous large follicles with highly flattened (squamous) epithelium and distended colloid lumen were a striking feature of the thyroid of these old goats and colloid droplet was a rare occurrence in this very strongly PAS- positive colloid (Fig. 5D).

Generally, during development the presence of stained colloid (H - E /PAS) increased strikingly from the 95-125 days foetal age. By pubertal age all follicles were fully distended with colloid. Colloid vacuolation were encountered from age of about 95-125 days representing the last trimester of gestation.

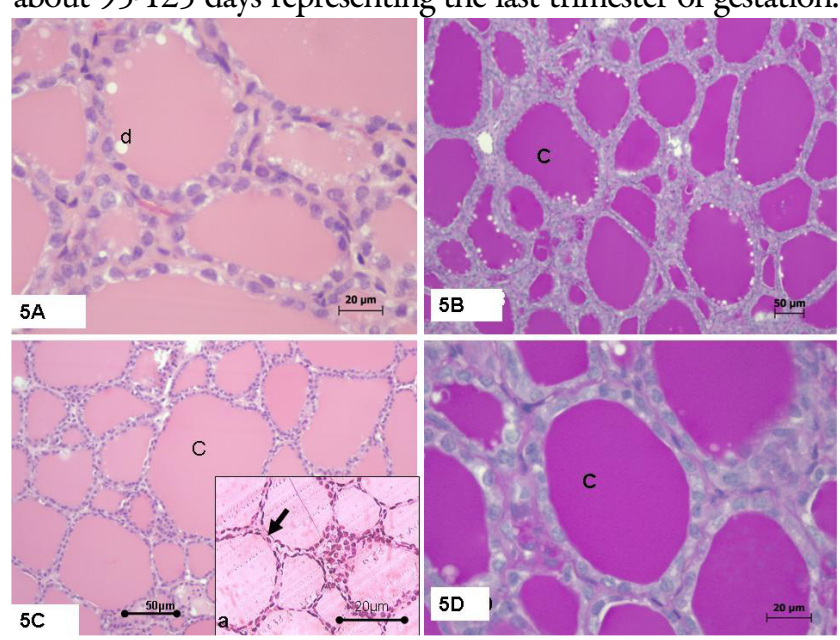

Fig. 5A. Photomicrograph of thyroid of goat of 1-2 years showing follicles of varied sizes distended with colloid and peripheral colloid droplets (d). H - E (bar scale $20 \mu \mathrm{m}$ ); Fig. 5B. PAS-stained sections of thyroid of 1-2 years showing strongly stained colloid (C) with peripheral vacuoles. PAS (scale bar $20 \mu \mathrm{m}$ ); Fig. 5C. Photomicrograph of thyroid of goats over three years old with hyperdistended follicles (C) with predominant flat cells (squamous) and in some sections with fibrotic interfollicular connective tissue (arrows-insert). $\mathrm{H}$ - E (scale bar $40 \mu \mathrm{m}$ ); Fig. 5D. Sections of thyroid of goat of above 3 years also showed strongly PAS-positive colloid with few colloid droplets. PAS (scale bar $20 \mu \mathrm{m}$ )
Medium and large-sized follicles were predominantly present from the prepubertal age in goats, while large colloid-distended follicles were a permanent feature of pubertal goats.

Significant variations in the mean follicular diameter, mean capsule thickness and mean epithelial cell height of the thyroids were observed in all stages of development. The mean large follicular diameter of in the foetal, pre-pubertal and pubertal ages were $17.70 \pm 0.09 \mu \mathrm{m}, 54.41 \pm 0.28 \mu \mathrm{m}, 142.77 \pm 0.51 \mu \mathrm{m}$ respectively. All measured histometric parameters increased with age except the epithelial cell height of older pubertal thyroids that decreased significantly $(p<0.05)$ (Table 1).

\section{Discussion}

It is generally accepted that increased function of the thyroid gland manifests itself by smaller follicles, higher follicular epithelium, increased quantity and eosinophilia of the colloid and by increased proliferative activity, indicated by mitotic figures (Fujita, 1975; Jelinek et al., 2003).

The present observation of significant increase of these histometrical indicators of functionality, along with the presence of colloid and other remarkable histological features during foetal development, indicated that the foetal thyroids are functional during gestation in this study. This is in consonant with the study of Thomas and Nathanielsz (1983) in sheep and Pickering (1968) in monkey.

The significant variations in the histometrical values relating to thyroid size amongst the foetal and postnatal ages is largely due to differences in the size and growth rate of the thyroid gland during the developmental period, as a result of varying nutritional, environmental and management factors. The range values obtained for medium follicular diameter of thyroid in pubertal goat $(80.6-100.6 \mu \mathrm{m})$ did not differ remarkably from the range values of follicular diameter obtained by Faysal and Levon (1978) in goat (89.7-102.8um). Slight differences in values may be as a result of differing animal breeds, varying environmental and metabolic rates which affect the weight of thyroid and diameter of thyroid follicles. Follicular size tends to increase with increasing body size, while epithelium percentage decreases. The existence of remarkably large follicles with much flattened epithelium was preponderant in the thyroid of older pubertal goat, with mean follicular diameter of $229.34 \mu \mathrm{m}$. These observations strongly suggest that ageing results in decreased activity of the thyroid gland resulting in slowing down of all mechanisms that lead to increased colloid utilization for the production of thyroid hormones. Comparatively the diameter of follicles of thyroid of adult Nubian goat ranges from 74.9-238 $\mu \mathrm{m}$ in winter and increases to $55.1-361.6 \mu \mathrm{m}$ in summer (Hamad, 2008). The differences may be due to age, breed and climatic factors.

The follicular cell height showed significant variations amongst the age groups. The mean cell height of late foetuses of

Table 1. The West African dwarf goat thyroid histometry

\begin{tabular}{|c|c|c|c|c|c|}
\hline Dev. aged/year & $\operatorname{SFD}(\mu \mathrm{m})$ & $\operatorname{MFD}(\mu \mathrm{m})$ & $\operatorname{LFD}(\mu \mathrm{m})$ & $\mathrm{CT}(\mu \mathrm{m})$ & $\mathrm{CH}(\mu \mathrm{m})$ \\
\hline $50-70 \mathrm{~d}$ & $17.11^{\mathrm{a}} \pm 0.15$ & $17.23^{\mathrm{a}} \pm 0.04$ & $17.70^{\mathrm{a}} \pm 0.09$ & $54.18^{\mathrm{a}} \pm 0.44$ & $7.56^{c} \pm 0.10$ \\
\hline $75-90 d$ & $23.01^{\mathrm{b}} \pm 0.19$ & $25.22^{b} \pm 0.36$ & $43.57^{b} \pm 0.30$ & $106.65^{b} \pm 0.83$ & $8.68^{\mathrm{d}} \pm 0.05$ \\
\hline $95-125 d$ & $25.10^{c} \pm 0.17$ & $32.65^{c} \pm 0.05$ & $57.28^{c} \pm 0.30$ & $106.61^{\mathrm{b}} \pm 1.03$ & $7.17^{\mathrm{b}} \pm 0.07$ \\
\hline Pubertal & $25.48^{\mathrm{d}} \pm 0.19$ & $47.55^{\mathrm{d}} \pm 0.33$ & $54.41^{\mathrm{d}} \pm 0.28$ & $110.19^{\mathrm{d}} \pm 1.04$ & $7.59^{c} \pm 0.07$ \\
\hline Pubertal 1-2yrs & $42.01^{\mathrm{d}} \pm 0.27$ & $62.35^{\mathrm{e}} \pm 0.12$ & $142.77^{\mathrm{e}} \pm 51$ & $110.19^{d} \pm 1.04$ & $8.51^{\mathrm{d}} \pm 0.10$ \\
\hline Pubertal < 3yrs & $51.39^{\mathrm{e}} \pm 0.32$ & $96.28^{f} \pm 0.14$ & $208.45^{\mathrm{f}} \pm 1.78$ & $133.54^{\mathrm{e}} \pm 1.93$ & $4.06^{a} \pm 0.06$ \\
\hline
\end{tabular}

$\mathrm{p}<0.05$, SFD (small follicle diameter, MFD (medium follicle diameter), LFD (large follicle diameter), CT (capsule thickness), CH (cell height). 
64

$7.17 \mu \mathrm{m}$, decreased remarkably to $4.06 \mu \mathrm{m}$. These histometrical changes are consistent with age-related changes in the growth of several peptide hormone secreting organs in mammals. Changes in epithelial height amongst thyroid of different age groups have been observed in goat (Roy et al., 1978b) and buffalo calves (Marthur, 1971). Titlbach et al. (1987) reported cuboidal to columnar epithelium in developing cat thyroid.

The thyroid follicles varied histologically in size (follicular diameter, capsular thickness and cell height) and shape during development. The present finding is in agreement with histological findings of the thyroids by Mathur (1971) in Asiatic water buffalo, Roy et al. $(1976,1978 b)$ in goat and Sawicki et al. (1992) in European bison. Sawicki et al. (1992) observed variability in size and shape of follicles in young bison which increased significantly in older animals, with large follicles in relatively great number noted in the very old bison. However, Ranjan et al. (2011) observed no change in the follicular lining epithelium during histogenesis of foetal thyroid of buffalo. These variations in follicular size amongst developmental stages could be as result of the influence of the several internal and environmental factors influencing thyroid development and function.

The current study showed that the early foetal thyroids in all species were surrounded by a thin capsule of dense irregular connective tissue which was continuous with well vascularised loose connective tissue septa that penetrated the parenchyma. This finding is supported by the study of histogenesis of thyroid in bovines by Shafie and Mashally (1974), Parker $e t$ al. (1980) in neonatal pig and in small ruminants (Bhardwaj et al., 2006) and El-Shammaa (1996) in rabbits. The present study did not observe a clear three-layered capsule seen in goats according to Adhikary et al. (2003). This may be due to histological methods of study. The parenchyma comprised solid cell clusters of follicular epithelial cells some of which surrounded small lumina. The follicular cells were low cuboidal with large centrally placed nucleus in foetuses, assumed high cuboidal or columnar shape in pre-pubertal and pubertal stages of the goats. However, in older pubertal groups, several large follicles contained flattened follicular cells with highly vascularised thin connective tissue. In addition, the older pubertal stages presented more fibrous stroma, more basophilic colloid, epithelium desquamation into enlarging follicles, increased number of interfollicular cells and complete wrapping with interfollicular connective tissue around each follicle. Similar findings of the above were made by Andrew and Andrew (1942) in the ageing human thyroid and Roy et al. (1978a) in goat. The follicular colloid showed a PAS-positive reaction with varying intensity from the mid-foetal stage. These histological findings indicated evidence of functional activity in the synthesis of thyroglobulin into follicular lumen to form colloid in the foetal age. The presence of colloid was equally reported in prenatal cattle and buffaloes by Shafie and Mashally (1974) and Ranjan et al. (2011), with varying intensity as well. PAS-positive colloid was detected in human foetal thyroid at $13^{\text {th }}$ to $14^{\text {th }}$ week of gestation (Gaikwad et al., 2012). It therefore shows that the appearance of colloid and development of follicles in goat takes place before birth and may be able to secrete colloid and thyroid hormones prenatally. This opinion is supported by report of Badawy et al. (1978) in the camel and Soliman et al. (2010) in the rabbit.
The mean follicular diameter increased as the animal progressed in age. They were usually round to oval in shape but varied in numbers of irregular, evaginated and invaginated follicles especially in very old pubertal animals. The active follicles shown by presence of colloid droplets, colloid and cuboidal to columnar cells (Banks, 1993), were usually small compared to inactive follicles during all stages of development in the animals studied. However, the diameter of the follicles showed tendency to increase in size with advancing age and became irregular in outline in thyroids of older animals (goat over 3 years). In the older pubertal animals, stratification of epithelium resulted in in multiple layers and papillary infoldings of the epithelial cell layer into the lumen. These multi-stratified cells may give rise to some ultimobranchial follicles observed in the foetal and pubertal goats used in this study. It must be mentioned that variations in the shape of the thyroid follicles in histological sections are also due to the plane of section of follicles and by shrinkage. Foetal thyroids undergo post-mortem autolytic changes relatively quickly and this can lead to a collapse of the glandular architecture and nearly solid appearance of the gland (Ernst, 2011).

It was observed that large follicles intermingled with few small follicles predominated in the inner part of lobe, while small follicles were commonly seen in the peripheral part close to the capsule in all animals studied. The present remark of arrangement of follicles is similar to what was reported in thyroid of goat (Adhikary et al., 2003) and buffalo (Ranjan et al., 2011). Similar reports were made in porcine (Miyagama et al., 1982) and camel (Ali, 1987). However, Adhikary et al. (2014) found larger thyroid follicles close to the capsule of thyroid of bulls (Bos indicus). The present finding is in contradiction with researches in rat and guinea pig, where follicles at the periphery are larger than those more centrally placed and in human thyroid where the follicles are of uniform size (Bloom and Fawcett, 1968). This variation from previous studies may be due to species differences in the thyroid histogenesis.

According to Roy et al. (1978b), very active follicles were lined by cells of simple cuboidal or columnar types, whereas in inactive follicles, it was lined by very low simple cuboidal to squamous cells. Therefore, the present report suggested that the low cuboidal epithelium encountered in early foetuses indicated poor secretory activity of thyroid hormones, while in the late foetal, prepubertal and pubertal stages, the high cuboidal or columnar epithelium indicated active thyroid activity (synthesis, secretion and resorption of thyroglobulin to release thyroid hormones). The flattened epithelium in the older pubertal animals suggested a resting phase of thyroid activity.

Few unusually large, irregular, tubular, colloid- filled follicles lined with stratified squamous epithelium, were observed in thyroid of prenatal (foetuses of 50-70 days) and pubertal (2-3 years) development in the two goat species but not in other animals studied. These follicles, which were presumed to be ultimobranchial (UB) follicles in this study, were found to be located in perivascular connective tissue around the major blood vessels in the centre of the thyroid lobe. This is similar to the result of Roy et al. (1978a) in postnatal goats of about 1 month to more than 5 years. The UB follicles seen in this study were always surrounded by small follicles. It can be deduced that these may be acting as a source of follicular 
cells and form new follicles. The contents of these UB follicles varied and were seen to consist of either cellular debris or noncellular colloidal debris. This cellular debris included nucleated cells, some of which were pyknotic. These contents suggest that they may be source of ultimobranchial cysts and even thyroid neoplasm in some thyroid of goats during development. The occurrence of the unusual follicles of ultimobranchial bodies have been reported in the thyroid of sheep (Van Dyke, 1959), European bison (Sawicki, 1991) and buffalo (Sayed et al., 2005). In mammals, the ultimobranchial bodies and /or follicles have been said to disappear or participate in the formation of thyroid follicles before birth and/ or after birth. The fate of the UB follicles present in the foetal goat may be that it disappeared in the adult thyroids or were missed out completely in the study.

Colloid droplets were demonstrated in the H-E and PAS stained sections. The presences of intrafollicular and intracellular vacuoles were observed from the foetal age to the pubertal age, with few droplets being encountered in the older pubertal animals. The preponderant colloid droplets in foetal thyroid of goat studied may be indicative of functionality and probably high activity of follicles at this stage of prenatal development. Comparatively, colloid droplets have been first observed in buffalo at 137 days of gestation in camel (Ranjan $e t$ al., 2011). El Sheikh et al. (1966) observed clear colloid droplets in the intra follicular colloids by 70 days of gestation in camel and Alwan (2009) reported its presence at 100 days in sheep. The presence of colloid and colloid droplets is indicative of secretory activity of the gland (Uchiyama et al., 1986a). Therefore, colloid droplets seen in the late foetal thyroids of goats represent evidence of prenatal function.

Parafollicular cells were seen clearly from late foetal stage to the postnatal period and appeared to increase in number with age of development. They were seen as single cells between follicular cells or as groups between follicles. These findings are in agreement to the findings in the Nubian goat (Hamad, 2008), in camel (Ali, 1987) and bovine (Suuroja et al., 2003). Parafollicular cells are responsible for calcitonin production and are not easily recognized with routine $\mathrm{H}$-E, especially in the fairly cellular-appearing foetal thyroid (Ernst, 2011).

\section{Conclusions}

The histological parameters of thyroids of WAD goats varied with increased age particularly in the cell height of the follicular cells of very old goats. These changes were related to the increasing functional requirement of the thyroid with age and complexity of the developing animal. The thyroid of midterm foetuses showed some morphological features related to thyroid function such as the presence of high cuboidal or columnar cells, the presence of PAS-positive colloid and colloid vacuoles. The current finding suggested possible high prenatal function for the thyroids of goats during the synthesis of thyroid hormones.

\section{References}

Adhikary GN, Quasem MA, Das SK, Khalil M (2003). A prospective study on histochemical observations of thyroid of pubertal black Bengal goat. Mymensingh Medical Journal 12(2):108-11.

Adhikary GN, Chowdhury SK, Sarkar S, Paul B, Islam KM, Islam MN
(2014). Histological observations of thyroid glands at prepubertal, pubertal and castrated adult indigenous bulls (Bos indicus). Journal Sylhet Agricultural University 1(2):147-153.

Ali AM (1987). Histological and morphometric study of some endocrine glands of the camel (Camelus dromedarius). MVSc thesis. University of Khartoum.

Alwan AE (2009). Sheep fetal thyroid development, with adult $\mathrm{T}_{4}$ and $\mathrm{T}_{3}$ hormones concentrations. Journal Animal Veterinary Advances 11(2):115-117.

Andrew W, Andrew NV (1942). Senile involution of the thyroid gland. American Journal Patholology 18:849-863.

Badawy YW, El-Keshaway AH, Ghallah AM, Abdou M, Selim AA (1978). Histological and histochemical studies on the prenatal development of the thyroid gland in camel (Camelus dromedaries). Egyptian Journal of Histology 6(2):365-375.

Baishya G, Ahmed S, Bhattacharya M (1985). Gross anatomical observations on male-gonad and thyroids gland in Assam goat (Capra hircus) during post-natal life (zero to ninety days). Indian Veterinary Journal 62:395-400.

Baishya G, Ahmed S, Bhattacharya M (1986). Histomorphological and histochemical study of thyroid gland of prepubertal Assam goat. Indian. Journal Animal Science 56:667-669.

Banks WJ (1993). Applied veterinary histology, third edition, MosbyYear Book Inc, USA pp 414415.

Bhardwaj R, Rajput R, Pathak V, Thaku K (2006). Comparative anatomy of the thyroid of small ruminants. Indian Journal Animal Science 76(1):46-47.

Bloom W, Fawcett DW (1968). A textbook of histology. WB Saunders, Philadelphia, ninth edition pp 89-96.

Chibuzo GA (2006). The teeth in ruminant dissection guide. A regional approach in goats, $2^{\text {nd }}$ revised ed. Beth-Bekka Academic Publishers, Maiduguri, Nigeria pp 59-61.

El-Shammaa AM (1996). Developmental studies on the thyroid gland of rabbits. Egypt Journal of Anatomy 19(1):207-227.

El-Sheikh AS, Rasheed AA, Amin SO (1966). Histological changes in the foetal thyroid of the dromedary (Camelus dromedarius). Journal of Anatomy 100(4):831-837.

Ernst LM (2011). Thyroid. In: Ernst LM, Ruchelli ED, HuffDS (Eds). Color atlas of fetal and neonatal histology, Springer Science, New York pp213-224.

Faysal A, Levon G (1978). A comparative study of the thyroid follicular size and epithelium percentage in certain mammals. Anatomische Anzeiger 143:96-99.

Fujita H (1975). Fine structure of the thyroid gland. International. Review of Cytology 40:197-274.

Gaikwad JR, Dope SA, Joshi DS (2012). Histogenesis of developing human thyroid. Indian Medical Gazette, Febr 57-61.

Hamad ESA (2008). Seasonal changes in the morphology and morphometry of thyroid gland of the Nubian goat. MVSc thesis, University of Khartoum.

Jelinek F, Krabacova I, Kroupova V (2003). Assessment of functional activity of the bovine thyroid gland using morphometry and two markers of cellular proliferation. Acta Veterinaria Brno 72:11-16. 
66

Kameda Y, Oyama H, Horino M (1984). Ontogeny of immunoreactive somatostatin in thyroid $\mathrm{C}$ cells from dogs. Anatomical Record 208(1):89-101.

Marthur ML (1971). Microscopic study of the thyroid gland of the Asiatic water buffalo (Bubalus bubalis). American Journal Veterinary Research 32 363-366.

Miyagawa J, Fujita H, Mastuda H (1982). Fine structural aspects of inverted follicles in cultured porcine thyroids. Archivum Histologica Japonicum 45(4):385-392.

Norris DO (2007). The vertebrate endocrinology, Philadelphia. Lea and Febiger pp 162-321.

Parker RO, Williams PEV, Aherne FX, Young BA (1980). Histological structure of the thyroid gland in neonatal pig. Biology of Neonate 38:120-125.

Pickering DE (1968). Thyroid physiology in the developing monkey fetus (Macaca mullatta). General and Comparative Endocrinology 10:182-190.

Ranjan R, Sharma A, Singh O, Bansal N (2011). Histogenesis of the thyroid gland in the buffalo. Indian Journal of Animal Science 81 (4):377-379.

Richardson C (1980). The development of the conceptus. In: Arthur, GH, Noakes OE, Pearson H, Parkinson T (Eds). Veterinary reproduction and obstetrics, $7^{\text {th }}$ edition. WB Saunders, London pp 51-62.

Roy KS, Saigal RP, Nanada BS, Nagpal SK (1976). Gross, histomorphological and histochemical changes in the thyroid gland of goat with age. III: Occurrence of thymic tissue. Anatomische Anzeiger 139(1-2):158-164.

Roy KS, Saigal RP, Nanda BS, Nagpal SK (1978a). Gross, histomorphological and histochemical changes in thyroid gland of goat with age. II: Occurrence of ultimobranchial follicles. Anatomische Anzeiger 142:72-85.

Roy KS, Saigal RP, Nanda BS, Nagpal KS (1978b). Gross, histomorphological and histochemical changes in thyroid gland of goat with age. IV; Histomorphological study. Anatomische Anzeiger 142:80-95.

Sayed R, Ahly KH, Mubarak W (2005). Surface ultrastructure of ultimobranchial remnants in the thyroid glands of buffalo (Bubalus bubalis). Anatomia Histologia Embryologia 34(1):45.
Sawicki B (1991). Ultimobranchial follicles and cysts in the European bison. Acta Theriologica 34 (3-4):349-356.

Sawicki B, Siuda S, Kasacka I (1992). Microscopic structure of the thyroid gland in the European bison. Acta Theriologica 37(12):171-179.

Schafie MM, Mashaly MM (1974). Prenatal and postnatal thyroid development in bovines. Acta Anatomica 87:615-634.

Solaiman SG (2010). Goat science and production. Iowa, WileyBlackwell pp 88-97.

Soliman SM, Nabil TM, El-Kerdawy AZ, El-Bayomy AM (2005). Development of the thyroid gland of the New-Zealand white rabbit. Beni-Suef Veterinary Medical Journal 15(2):1-8.

Suuroja T, Jarveots T, Lepp E (2003). Age-related morphological changes of thyroid gland in calves. Veterinarija IR. Zoo Technica 23(45):55-59.

Thomas AL, Nathanielsz PW (1983). The fetal thyroid. In: Martini I, James VHT (Eds). Current topics in experimental endocrinololgy Vol. 5: Fetal endocrinology and metabolism. Academic Press, New York pp 97-110.

Titlback M, Veliky J, Lhotova H (1987). Prenatal development of cat thyroid; Immunohistochemical demonstration of calcitonin in the C cells. Anatomy Embryology 177:51-54.

Uchiyama Y, Murakami G, Igarashi M (1986). Changes in colloid droplets and bodies in rat thyroid follicular cells during 24 hours. Fine structural and morphometric studies. American Journal Anatomy 175:15-22.

Van Dyke JH (1959). The ultimobranchial body. In: Gorbman A (Ed). Comparative endocrinology. Proceedings Symposium on Comparative Endocrinology, New York, John Wiley pp 320-339.

Venzke WG (1975). Endocrinology. In: Getty R (Ed). Sisson and Grossman's The Anatomy of Domestic Animals, $5^{\text {th }}$ edition. WB Saunders, Philadelphia pp 955-959.

Young B, Heath JW (2000). Wheater's functional histology, Churchill Livingstone, Toronto pp 315-317. 